\title{
先天性第X因子欠乏症患者における抜歯経験
}

\author{
京本博行・澈田正亮 \\ 西川典良・高尾宏昭

\section{Experience with tooth extraction in a patient who had congenital factor $\mathrm{X}$ deficiency}

\author{
KYOMOTO Hiroyuki · TAKITA Masaaki \\ NISHIKAWA Noriyoshi · TAKAO Hiroaki
}

\begin{abstract}
Congenital factor $X$ deficiency is a very rare disease. We present a case of marginal periodontitis in a patient with congenital factor $X$ deficiency. The patient was a 53-year-old woman in whom congenital factor $X$ deficiency was diagnosed on the detection of bloody urine. Our department was consulted by her physician because of swelling of the gingiva around the maxillary right second molar. After administering antibiotic treatment, tooth extraction was performed. The tooth socket was filled with oxidized cellulose, and the gingival defect was primarily closed, achieving good local status. However, continuous oozing from the socket of the tooth increased gradually the next day. Then, the patient was given combined Coagulation Factor Complex (PPSB-HT ${ }^{\circledR}$ ), 1000 units. The factor X activity in serum increased from $7 \%$ to $49 \%$ the day after treatment was initiated. Although the suture was removed on the 7th postoperative day, slight persistent bleeding was observed. Bleeding stopped when thrombin liquid was sprayed over the site of bleeding and pressure was applied with gauze. There was no abnormal hemorrhage, and wound healing was uneventful.
\end{abstract}

Key words: congenital factor X deficiency（先天性第 X因子久乏症， coagulation factor（凝固因子）, tooth extraction (抜柬)

\section{緒言}

先天性第 X因子欠乏症はきわめてまれな疾患で，その発 症率は 50 万人に 1 人といわれている. また, 本疾患は男女 両性に認められ，常染色体劣性遺伝形式を示すと考えられ ている ${ }^{1)}$. 先天性第X因子久乏症による出血は比較的軽症 なものが多いとされている ${ }^{2)}$ が, 内因系, 外因系の共通部 分の異常のため, プロトロンビン時間 (以下 PT), 活性化 部分トロンボプラスチン時間（以下 APTT） は延長し出血 傾向を示す ${ }^{1)}$. このため, 茵科口腔外科領域で一般的な観 血的処置である抜㐘の際には十分な注意を払う必要性があ ると考えられる. 今回，われわれは先天性第 X因子欠乏症 患者の抜茵を経験したので, その概要について報告する.

大阪府済生会中津病院柬科口腔外科

(主任：澈田正亮部長)

Department of Dentistry and Oral Surgery, Saiseikai Nakatsu Hospital, Osaka (Chief: TAKITA Masaaki)

受付日：2006 年 1 月 6 日

採択日：2006 年 8 月 21 日
症例

患 者: 53 歳, 女性.

初 診：2004 年 12 月.

主 訴：７近心柬肉の腫脹, 自発痛.

既往歴： 4 年前に血尿のため当院内科受診し, 血液凝固 因子量の検索において先天性第 X因子欠乏症であることが 明らかとなった。その際にB型肝炎に罹患していることを 指摘された。 また，その後の遺伝子解析により複合へテロ 接合体であると診断されていた。過去には月経過多や, 出 産時に弛緩出血が認められたことなどが問診で聴取され た。また，初診より 6 年前に子宮筋腫摘出手術を受けてい たが，その際に600ccの輸血を受けていた.

家族歴：患者は東アジア系外国人であるため詳細な調査 は行えなかったが，異常出血が認められる親族は思い当た らないとのことであった。

現病歴：初診 2 日前より 7 近心側の柬肉の腫脹, 自発 痛を認めたため, 内科医の紹介により当科を受診した.

全身所見：眼瞼結膜，眼球結膜には貧血，黄㾝はなく， やや肥満気味であるが特に異常所見を認めなかった。 


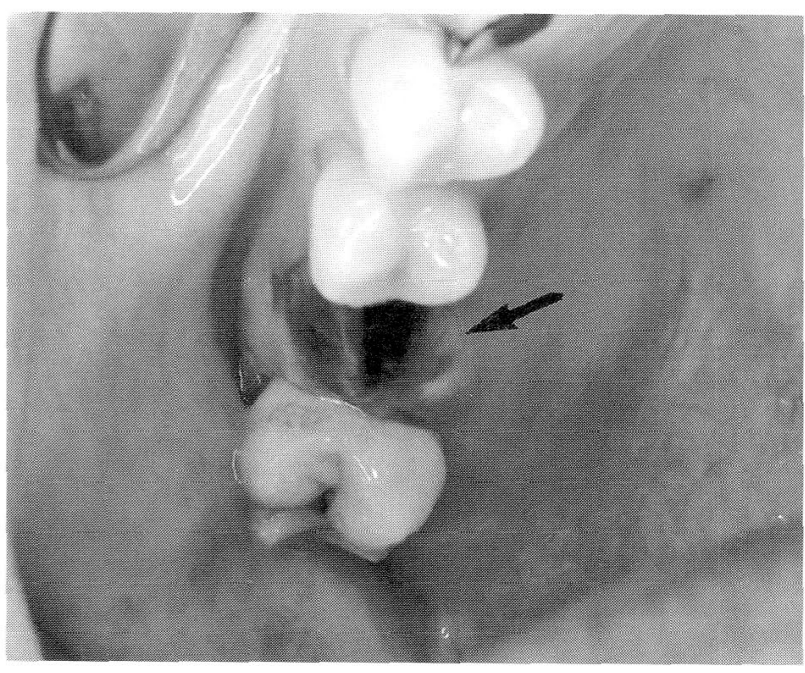

写真 1 初䛦時口腔内写真

7 近心蒾肉は暗赤色を示し, 内出血斑が認められた。

口腔内所見：7」は軽度の動摇が認められ，近心雷肉か ら 6 相当部蒾肉に至るまで,びまん性に腫脹していた 6」は欠損しており, 同㐘肉は暗赤色となり内出血様症状 を呈していた．７近心㐘周ポケットは $13 \mathrm{~mm}$ と深く易出 血性で自発痛を認めた（写真 1)

$\mathbf{X}$ 線所見：パノラマX線写真では 7 近心歯槽骨の吸収 が認められ，慢性辺縁性歯周炎の様相を呈していた（写真 2 ).

臨床診断：7 慢性辺縁性柬周炎急性増悪.

臨床検查所見：一般血液検査では白血球数 $9100 / \mu 1$, $\mathrm{CRP} 17.2 \mathrm{mg} / \mathrm{dl}$ と高值を示していた。凝血学的検査では PT が 40.9 秒，APTT が 67.7 秒と延長，第X因子活性が $7 \%$ と低值を示していた。また，生化学検査では肝機能検 查值に異常は認められなかった（表 1).

治療経過： 7 近心歯肉のびまん性腫脹，自発痛を認め， CRP 流值を示していたため，外米通院下，セフポドキシ ムプロキセチル $200 \mathrm{mg} /$ 日を 7 日間投与し消炎を行った。 腫脹は経日的に改善傾向を示した。今後の炎症再燃を予防 するため，７抜夹並びに周囲不良肉芽組織の掻爬を行う ことを予定した。先天性第X因子久乏症による出血には血 友病と比較すると重篤なものが少ないとされていることか ら, 内科医と相談の上, 術前の補充療法は行わないことと した．抜蒾後出血への対応として第X因子を含有する複合 型凝固因子製剤 PPSB-HT ${ }^{\circledR}$ を用意した。 入院管理のもと， 局所麻酔下に 7 の抜柬を行うこととした。まず， 7 柬肉 頓移行部, 次いで 7 蒾冠周囲蒾肉に 8 万倍エピネフリン 含有 $2 \%$ リドカインを計 $1.8 \mathrm{ml}$ 使用し浸潤麻酔を行った。

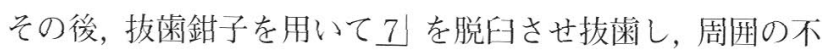

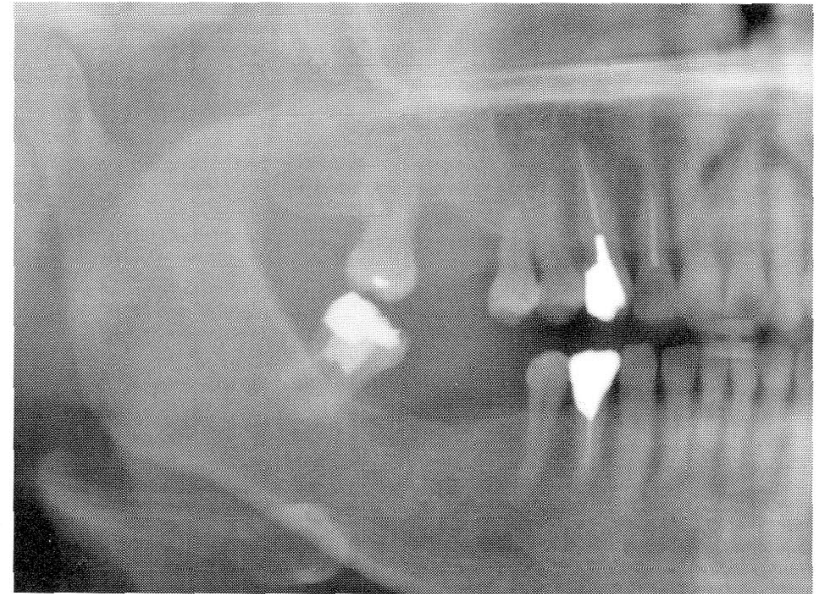

写真 2 初骖時パノラマX 線写真

7 近心蒾槽突起は慢性辺縁性雪周炎による骨吸収像 が認められる。

表 1 当科初診時の臨床検查結果

\begin{tabular}{|c|c|c|c|c|}
\hline \multicolumn{3}{|l|}{ 血液一般検査 } & \multicolumn{2}{|l|}{ 生化学検査 } \\
\hline $\mathrm{RBC}$ & $483 x$ & $<10^{4} / \mu 1$ & CRP & $17.2 \mathrm{mg} / \mathrm{dl}$ \\
\hline WBC & 9100 & $/ \mu 1$ & T-Bil & $0.7 \mathrm{mg} / \mathrm{dl}$ \\
\hline $\mathrm{Hb}$ & $13.9 \mathrm{~g}$ & $\mathrm{~g} / \mathrm{dl}$ & BUN & $19.6 \mathrm{mg} / \mathrm{dl}$ \\
\hline Het & 43.5 & & Creatinine & $0.7 \mathrm{mg} / \mathrm{dl}$ \\
\hline Plate & 31.6 & $\times 10^{4} / \mu 1$ & GOT & $28 \mathrm{IU} / \ell$ \\
\hline 凝恤学的㭘查 & & & GPT & $35 \mathrm{IU} / \mathrm{e}$ \\
\hline 出血時間 & & 2 分 & $\mathrm{LDH}$ & $213 \mathrm{IU} / \ell$ \\
\hline PT & & 40.9秒 & $\gamma$-GTP & $33 \mathrm{IU} / \mathrm{e}$ \\
\hline APTT & & 67.7秒 & ALP & $177 \mathrm{IU} / \ell$ \\
\hline トロンボテス & & $9 \%$ & CK & $87 \mathrm{IU} / \ell$ \\
\hline フィブリノー & ゲン & $326 \mathrm{mg} / \mathrm{dl}$ & $\mathrm{TP}$ & $6.9 \mathrm{~g} / \mathrm{dl}$ \\
\hline 凝固因子活性 & $(X)$ & $7 \%$ & アルブミン & $4.4 \mathrm{~g} / \mathrm{dl}$ \\
\hline
\end{tabular}

良肉芽組織を掻爬のうえ，抜蒌窩に酸化セルロース綿を填 塞して緊密に周囲粘膜を縫合し，ガーゼで圧迫止血を行つ た。術当日，翌日とガーゼによる圧迫止血を継続したが， 少量の持続的な出血は完全には制御されなかった。また， 抜茵当日夕食より経口掑取開始とするが, 出血が気になり

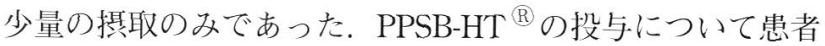
の同意を得た後，術翌日 PPSB-HT ${ }^{\circledR} 1000$ 単位を投与した ところ, 術後 2 日目にはPT 16.1 秒, APTT 36.7 秒と短縮が 認められ，第X因子活性は $49 \%$ と改善した。止血状態は良 好となり，術後 3 日目には完全に止血したため，以降の追 加投与は行わなかった。創部治癒状態良好のため術後 5 日 目に退院とした。術後 7 日目に抜系を行ったが，少量の持 
表 2 抜㐘前後の止血能の推移

\begin{tabular}{cccccc}
\hline 測定項目 & 術当日 & 術後 2 日 & 術後 3日 & 術後 4 日 & 術後 7日 \\
\hline APTT & 59.1 秒 & 36.7 秒 & 40.6 秒 & 44.4 秒 & 51.5 秒 \\
PT & 36.2 秒 & 16.1 秒 & 18.3 秒 & 20.9 秒 & 28.0 秒 \\
第X因子 & $7 \%$ & $49 \%$ & $33 \%$ & & \\
\hline
\end{tabular}

APTT：活性化部分トロンボプラスチン時間 PT：プロトロンビン時間

表 3 本邦に打ける先天性凝固障害症の生存患者数

\begin{tabular}{lrrrrr}
\hline \multicolumn{1}{c}{ 疾 患 名 } & 1976 & 1981 & 1986 & 1991 & $1998(5 / 31)$ \\
\hline 血友病 A & 2129 & 2188 & 2837 & 3145 & 3442 \\
血友病 B & 431 & 419 & 559 & 646 & 724 \\
第X因子欠乏症 ・異常症 ${ }^{*}$ & 7 & 7 & 11 & 12 & 11 \\
\hline
\end{tabular}

*第 X因子の分子異常により機能低下を起こすものは第 $X$ 因子異常症とされている ${ }^{1)}$.

続的出血を認めた。凝血学的検査ではPT 28.0 秒, APTT 51.5 秒とPPSB-HT ${ }^{\circledR}$ 投与前の水準に戻っていた（表 2). 圧迫止血を行ったが，容易には止血しなかったため，ト口 ンビン液を散布し压迫止血を行ったところ止血した．以後 は異常出血を認めず治癒状態は良好であった。

\section{考察}

先天性第 X因子欠乏症は, 内因系および外因系の両凝固 系に関与する第 X因子の欠そによる遺伝性出血性疾患であ る. 1956 年に Telfer ら ${ }^{3)}$ が Prower 症例を, 1957 年には Hougie ${ }^{4)}$ が Stuart 症例を報告した. 以後 1983 年までに 世界中で 50 家系以上の確定例が報告されている．わが国 では 1964 年安永ら ${ }^{5 ）}$ が第 1 例を報告しており，1998 年 5 月 31 日の血液凝固異常症全国調査では，第X因子久乏 症・異常症の生存総数は 11 名とされている (表 3 $)^{6)}$. 本 疾患は常染色体劣性遺伝形式を示すとされ，へテロ接合体 では無症状であることが多いといわれているが，ホモ接合 体もしくは複合へテロ接合体では出血傾向を示すとされて いる ${ }^{7)}$. 外因系抢よび内因系凝固の障害を示す検査所見が 特徴的であるが, 出血症状は血友病に比較すると軽度であ る.また，関節出血のように重篤な出血はまれであるが， 紫斑，鼻出血，雬肉出血，血腫形成，月経過多などをきた し，創出血や術後出血が多いとされている ${ }^{8)}$. 今回のよう な抜菌などの小手術では，第 X因子活性の低下があっても， 血小板による一次止血により一時的な止血状態は維持され る。しかし，欠乏因子の補充を行わなければ数時間後に必
ず出血し血腫を形成し, 再出血を繰り返すとされている ${ }^{9)}$. 国内での先天性第X 因子久乏症の患者で外科手術を施行 した報告はきわめて少なく，近年では 1994 年に渡辺ら ${ }^{2)}$ が進行胃癌の切除手術を報告している. 渡辺ら ${ }^{2)}$ の報告例 はへテロ接合体であり, 第X因子活性は $39 \%$ ああった。こ の報告例は，複合へテロ接合体の症例に比べ出血傾向は軽 微であるが, 進行胃癌の切除手術であるため, PPSB-HT ${ }^{\circledR}$ を術前から術後まで投与している.

一方，第X因子の生体内半減期は約 2 日である ${ }^{8)}$ とされ ているが，一般に抜菊 3 日後には血餅の器質化が進み始め ているとされている10）ため，第X因子活性は 2 日程度維 持されれば，抜菊後の止血には十分であると考えられる. 抜歯後の出血については想定していたが，局所止血法での 対応を試み，本例では PPSB-HT ${ }^{\circledR} の$ 前投与は行わなかっ た.これは，先天性第 X因子欠乏症では血友病と比較して 出血は軽症であることが多いとされていることや ${ }^{8)}$, 患者 が血液製浏の使用について不安を訴えていたことによる.

患者は B 型肝炎に罹患していることから，血液製郕に対 する不安感が強く可能であれば使用しないことを希望して いた，しかし，術翌日に完全に止血せず出血傾向が継続し， 最終的に PPSB-HT ${ }^{\circledR}$ の使用に同意した. PPSB-HT ${ }^{\circledR} 1000$ 単位投与の翌日には，第X因子活性は $49 \%$ 上昇し，止血 状態は良好となった。

第X因子の補充を目的として製造された凝固因子製剂は ないが，複合型凝固因子製剂であるPPSB-HT ${ }^{\circledR}$ は第 X因 子を含有する。PPSB-HT ${ }^{\circledR}$ は一般的に第IX因子製剤とし 
て，血友病 B 患者に使用され，第IX因子活性に関しては体 重 $1 \mathrm{~kg}$ あたり 1 単位の投与により約 $1 \%$ 上昇が期待で きるとされている ${ }^{9)}$.しかし，PPSB-HT ${ }^{\circledR}$ を使用した際の 第 X因子活性の上昇率に関しては，これまで詳細な検討が なされていない.このため，本症患者に対して PPSB-HT ${ }^{\circledR}$ の投与が想定される場合では，輸注試験により第X因子活 性の上昇率を確認する必要があると考えられる。しかし， 自験例では単純抜柬症例であり，出血量は少量であること が予想されたため，輸注試験は行わず，渡辺ら ${ }^{2)}$ の報告を 参考にして投与量を決定した。渡辺ら ${ }^{2)}$ は第X因子活性の 上昇を目的とした PPSB-HT ${ }^{\circledR}$ の補充量を計算する際，ま ずは第 $\mathrm{XX}$ 因子活性の上昇を目的とした補充量の計算式〔補 充量 $($ 単位 $)=($ 目標濃度一患者の凝固因子濃度 $) \% \times$ 体 重了により，補充量の算出を行っている，しかし，同計算 式で算出した補充量により，第X因子活性は期待值の倍程 度まで上昇している。このため，この計算式で決定される 補充量の半量程度で目標とする第X因子活性が得られるこ とが推測された。

第 X因子活性の目標值の設定は血友病患者で必要とされ る凝固因子活性を参考とした，血友病 $\mathrm{A}$ で 40 〜 $80 \%$ ，血 友病 B で 30 〜 $60 \%$ 程度の凝固因子活性が必要とされて いる ${ }^{9)}$. 本疾患は血友病と比較して出血傾向は軽症である ことから，凝固因子活性は $40 \%$ 程度を目標として補充量 を算出した．本症例の経過から単純抜菌と周囲不良肉芽組 織の掻爬では第X因子活性は 40 ～50\%程度であれば十分 に止血可能であることが示唆された.

しかし，凝固因子製剤にはインヒビタ一の発生や，未知 のウイルスによる感染などの危険性は皆無ではない ${ }^{11)}$. ま た，複合型凝固因子製剂では，副作用として凝固因子製剂 中に混入している他の活性型凝固因子のために DIC が誘 発される可能性も指摘されている ${ }^{2)}$ ，先天性第X因子欠乏 症患者の抜荗における局所止血は言うまでもなく重要であ り，安易に凝固因子製剤を使用すべきではなく，病態に応 じて，有効性が得られる最小限の投与量の決定が必要であ ると考えられた。

\section{結語}

今回われわれは，先天性第X因子欠乏症患者の抜柬後出 血に対して，複合型凝固因子製剂を用いる補充療法を行っ た，抜柬後の止血状態，治癒経過は良好であった，病態に 応じた投与時期と至適投与量が重要であることが示唆され た。

謝辞

稿を終えるにあたり，本症の診断につき御助言をいただき ました済生会中津病院腎臟内科 桑原 隆先生に深く謝意を表 します.

\section{引用 文 献}

1）諏訪庸夫編：血液症候群 II 。日本臨牀社，大阪， 1998, 442-444 頁.

2）渡辺 透，大村健二，他：先天性凝固第 X因子欠乏 症を伴った進行胃癌の 1 切除例. 日消外会誌 27: 1810-1814 1994.

3) Telfer, T.P., Denson, K.W., et al.: A new coagulation defect. Br J Haematol 2: 308-318 1956.

4) Hougie, C., Barrow, E.M., et al.: Stuart clotting defect. Segation of an hereditary haemorrhagic state from the heterogeneous group heterofore called stable factors (SPCA) deficiency. J Clin Invest 36: 4854961957.

5）安永幸二郎，岡本恵美子，他：先天性第 X因子欠乏 症の 1 例（抄). 日血会誌 27: 3771964 .

6）諏訪庸夫編：本邦臨床統計集（1）。日本臨牀 59 巻 増刊号 7，第 4 版，日本臨牀社，大阪，2001，459-469 頁.

7）鎌田健司，宮田敏行：凝固 $\mathrm{X}$ a 因子の立体構造. 血 栓止血誌 10: 217-222 1999 .

8）三輪史郎，青木延雄，他：血液病学. 第 2 版，文光 堂, 東京, 2000, 1281-1282 頁.

9）桐田忠昭，森本佳成，他：血友病の治療。吉岡 章; ヘモフィリア治療の最前線. 医科学出版社, 東 京, 2002, 52-57 頁.

10）上條雍彦：口腔解剖学 第 3 巻. 第 3 版, アナトー 么社，東京，2001, 572 頁.

11）熊谷康司，宇佐美雄司，他：血友病 $\mathrm{A}$ 患者の抜㐘に 扣ける臨床統計学的検討. 口科誌 45: 169-173 1996. 